УДК 37.078

DOI https://doi.org/10.32836/2310-9653-2020-3.7

С. П. Карапиш, здобувач вищої освіти ступеня доктора фрілософії Навчально-наукового інституту економіки, управління, права та інформаційних технологій Полтавської державної аграрної академії, заступник директора з навчально-виховної роботи Наукового ліцею № 3 Полтавської міської ради

\title{
УПРОВАДЖЕННЯ ІНФОРМАЦЙНО-КОМУНІКАЦІЙНИХ ТЕХНОЛОГІЙ У СИСТЕМУ УПРАВЛІННЯ ЗАГАЛЬНОЇ СЕРЕДНЬОЇ ОСВІТИ
}

У статті розглянуто інформаиійно-комунікаційні технологї як основний каталізатор інноваиійної діяльності сучасного педагога й управліния та один з особливо важливих системних компонентів іміджу органів державної влади в галузі освіти. Проаналізовано функиї інформаційно-комунікаиійної взаємодії в системі загальної середньої освіти. Визначено, щчо основним інформаційним каналом у системі управління освітою та потужним інструментом для побудови інноваційних форм управління є інтернет-засоби й сервіс-засоби. У статті визначено поняття інформачійно-освітнього середовища в системі освіти.

Доведено, щөо швидкий розвиток інформаиійно-комунікаиійних технологій, зростання рівня опанування комп'ютерною технікою суб'єктів освітнього процесу, відкритість освітніх систем, популярність електронних освітніх ресурсів $i$ віртуалізачія навчальної діяльності, потреба в інформачійній взаємодії та контактах соиіального партнерства, перехід до нової, активної форми фіксачії процесу й результатів освітньої діяльності актуалізували проблему формування та розвитку інформаційно-освітнього середовища в системі освіти. Дослідження в статті підводяться до рекомендащій: для ефективної модернізаиії освіти й оновлення технічного арсеналу засобів навчання необхідно оптимізувати реалізацію державних програм, спрямованих на інформатизацію, комп'ютеризацію та оновлення матеріально-технічної бази шкіл, надання всім вільного доступу до мережі Інтернет. Підготовка керівників до сучасного управління школою за допомогою інформаиійно-комунікаційних технологій є дієвим складником ефективного освітнього менеджменту.

Визначено, щзо інформачійні технології позитивно впливають на всі компоненти системи навчання: мету, зміст, методи й організаційні форми навчання, засоби навчання, щзо дозволяє розв'язувати складні й актуальні завдання в системі освіти для забезпечення розвитку інтелектуального, творчого потениіалу, аналітичного мислення та самостійності працівників. У статті також проаналізовано використання Інтернету в управлінні як одного з важливих інформаційнокомунікаційних механізмів забезпечення інноваційності, відкритості й прозорості діяльності в галузі освіти. На основі певних принципів розвитку інформаційного суспільства в статті систематизовано основні напрямки впровадження інформаиійно-комунікаційних технологій у системі управління освітою.

Ключові слова: інформаційно-комунікащійні технології, інформачійні ресурси, управління освіти, система загальної середньої освіти, управлінська діяльність, інформаційне суспільство.

S. P. Karapysh. Implementation information and communication technologies in the management system of general secondary education

The article considers information and communication technologies as the main catalyst of innovative activity of a modern teacher and manager and one of the especially important system components of the image of public authorities in the field of education. The functions of information and communication interaction in the system of general secondary education are analyzed. It is determined that the main information channel in the education management system and a powerful tool for building innovative forms of management are Internet tools and service tools. The article defines the concept of information and educational environment in the education system.

It is proved that the rapid development of information and communication technologies, the growth of computer skills in the educational process, the openness of educational systems, the popularity of electronic educational resources and virtualization of educational activities, the need for information interaction and social partnership contacts, the transition to a new, active form of fixing the process and results of educational activities actualized the problem of formation and development of information and educational environment in the education system.

The research in the article is based on the recommendations: for effective modernization of education and updating the technical arsenal of teaching aids it is necessary to optimize the implementation of state programs aimed at informatization, computerization and updating of schools, providing free access to the Internet. Preparing leaders for modern school management through ICT is an effective component of effective educational management.

It is determined that information technologies have a positive effect on all components of the training system: purpose, content, methods and organizational forms of training, teaching aids, which allows to solve complex and relevant problems in education to ensure intellectual, creative, analytical thinking and independence. The article also analyzes the use of the Internet in management

(C) С. П. Карапиш, 2020 
as one of the important information and communication mechanisms to ensure innovation, openness and transparency in education. Based on certain principles of information society development, the article systematizes the main directions of introduction of information and communication technologies in the education management system.

Key words: information and communication technologies, information resources, Department of Education, general secondary education system, management activities, information society.

Постановка проблеми. Модернізація управління якістю освітньої галузі передбачає оптимізацію організаційно-управлінських структур, зміни в технології реалізації управлінських функцій, впровадження інформаційно-управлінських і комп’ютерних технологій.

На зміну державній системі, влаштованій навколо апарату управління, поступово приходить модель «сервісної держави», у фокусі якої перебуває громадянин. Розвиток інформаційних технологій (далі - IT) визначає на порозі XXI ст. певний рівень розвитку держави, а поєднання теорій управління, комунікації та обчислювальної техніки спроможне забезпечити розробку раціональної структури й функціонування соціальних систем, до яких відносять як систему освіти загалом, так і окремі іiі ланки. Нові технологічні можливості дозволяють державі бути максимально адаптованою до потреб кожного конкретного громадянина, враховувати особливості кожної сім’ї. Інформаційні технології - це не мета, а засіб результативного й ефективного виконання службових завдань державним апаратом управління в інтересах кожного громадянина нашої держави.

Аналіз останніх досліджень і публікацій. Кількість досліджень, предметом яких стало використання інформаційно-комунікаційних технологій у навчальному процесі, значно зростає. Аналіз досліджень у галузі управління освітою свідчить про чималі напрацювання науковців, дослідників, які присвячені особливостям використання інформаційних ресурсів у процесі управління, визначення інформаційних потреб споживачів інформації в соціальній сфері, зокрема в освіті. Слід виділити дослідження таких науковців, як В.Ю. Биков, Я.В. Булахова, О.М. Бондаренко, В.Ф. Заболотний, Г.О., А.Б. Антопольський, О.В. Артюшків, В.Ю. Бодряков, В.В. Бойко, Г.І. Бритченко, Н.О. Вербицька, О.В. Єльнікова, Л.М. Калініна, І.К. Корнєєв, С.П. Кудрявцева, А.Н. Мартинов, С. В. Ніколаєнко й інші.

Мета статті - дослідити впровадження інформаційно-комунікаційних технологій в систему управління загальної середньої освіти, розкрити їхнє місце у взаємодії відносин держави й інформаційного суспільства.

Виклад основного матеріалу. Розробка державної освітньої політики має грунтуватися на всебічному аналізі, метою якого $є$ виявлення та порівняння можливих варіантів, встановлення пріоритетних напрямів для фінансування, управління, планування системи освіти й контролю за нею, насамперед в умовах інформаційного суспільства.

Ще у 2013 році урядом було схвалено Стратегію розвитку інформаційного суспільства в Україні [1]. Вагоме значення розширення сфери запровадження та використання інформаційно-комунікаційних технологій було підкреслено й у 2016 році в ході парламентських слухань у Верховній Раді України на тему «Реформи галузі інформаційно-комунікаційних технологій і розвиток інформаційного простору України». У рекомендаціях, схвалених постановою українського парламенту за результатами проведених слухань, наголошувалося, що «стан розбудови інформаційного суспільства й сфери ІКТ в Україні порівняно зі світовими тенденціями недостатній і не відповідає стратегічним цілям розвитку України, оскільки: існують суттєві проблеми з формуванням і реалізацією ефективної державної політики, зокрема у сфері розвитку інформаційного суспільства <...> [2].

Комітет Верховної Ради України з питань інформатизації та зв’язку розглянув на своєму засіданні 06 березня 2019 року (протокол № 94) проєкт Закону України «Про внесення змін до Закону України «Про Національну програму інформатизації», зареєстрований за № 9166, поданий 04 жовтня 2018 р. Кабінетом Міністрів України. Законопроєктом пропонується внести зміни й доповнення, якими зокрема передбачається: забезпечення інфраструктурних потреб розвитку інформаційного суспільства, формування та використання національних електронних інформаційних ресурсів, впровадження сучасних інформаційно-комунікаційних технологій для підтримки органів державної влади й органів місцевого самоврядування, соціально-економічної, екологічної, науково-технічної, оборонної, національно-культурної та іншої діяльності у сферах загальнодержавного значення та інше.

Серед ключових компетентностей освітніх стандартів, що тепер запроваджуються в Україні новим Законом «Про освіту» (2017 року) [3] й Концепцією Нової української школи [4], найважливішими в розрізі порушеної проблеми є: інформаційно-цифрова компетентність (уміле й критичне застосування інформаційно-комунікаційних технологій для створення, пошуку, обробки, обміну інформацією на робочому місці, в публічному просторі й приватному спілкуванні, інформаційна й медіаграмотність) і вміння вчитися впродовж життя (здатність до пошуку й засвоєння нових знань, набуття нових вмінь і навичок, організації навчального процесу (власного й колективного), зокрема через ефективне керування ресурсами й інформаційними потоками, вміння визначати навчальні цілі й способи їх досягнення, вибудовувати свою освітньо-професійну траєкторію, оцінювати власні результати навчання).

Інформаційно-комунікаційні технології (далі - IКТ, від англ. Information and communications technology, ICT) часто використовуються як синонім до інформаційних технологій (IT), хоча IКТ - це загальніший термін, який 
підкреслює роль уніфікованих технологій та інтеграцію телекомунікацій (телефонних ліній і бездротових з'єднань), комп'ютерів, підпрограмного забезпечення, програмного забезпечення, накопичувальних та аудіовізуальних систем, які дозволяють користувачам створювати, одержувати доступ, зберігати, передавати й змінювати інформацію. Іншими словами, ІКТ складається з IT, а також телекомунікацій, медіатрансляцій, усіх видів аудіо й відеообробки, передачі, мережевих функцій управління та моніторингу [5].

Необхідність використання інформаційно-комунікаційних технологій (ІКТ) в управлінні якістю освіти визначається рядом чинників: сучасні ІКТ, підвищуючи якість навчання та освіти, дають змогу людині успішніше й швидше адаптуватися до навколишнього середовища, до соціальних змін; активне й ефективне впровадження цих технологій в освіту є важливим чинником створення нової системи освіти, що відповідає вимогам процесу модернізації традиційної системи освіти.

Інформаційно-комунікаційні технології залежно від ступеня централізації здійснення процесу класифікують на централізовані, децентралізовані й змішані. Централізовані інформаційно-комунікаційні технології характеризуються тим, що обробка інформації та розв’язання завдань залежить від центрального органу й контролюються ним же. Децентралізовані використовуються на локальному, місцевому рівні. Змішані ІКТ поєднують у собі централізовані й децентралізовані. Розв’язання питань, проблем, обробка інформації можуть відбуватись на локальному рівні, але дані зберігаються в центральному органі, базах даних центральних органів.

Швидкий розвиток інформаційно-комунікаційних технологій, зростання рівня опанування комп’ютерною технікою суб'єктів освітнього процесу, відкритість освітніх систем, популярність електронних освітніх ресурсів і віртуалізація навчальної діяльності, потреба в інформаційній взаємодії та контактах соціального партнерства, перехід до нової, активної форми фіксації процесу й результатів освітньої діяльності актуалізували проблему формування та розвитку інформаційно-освітнього середовища в системі освіти.

Інформаційно-освітнє середовище постійно розвивається, уможливлює реалізацію нових раціональних підходів, застосування інноваційних форм і методів навчання (В.Ю. Биков, В.М. Кухаренко) [6].

Організація єдиного освітнього простору системи освіти дозволяє управлінню освіти:

- створити єдине інформаційне освітнє середовище закладів освіти області, міста, району;

- організувати дієвий документообіг у межах однієї установи, впровадити інформаційно-комунікаційні технології управління освітніми закладами дошкільної освіти, закладами загальної середньої освіти, закладами позашкільної освіти тощо;

- забезпечити електронний документообіг між управлінням освітою (далі - УО) й підпорядкованими закладами освіти, методичними службами; систему збирання, перероблення інформації з різних напрямів освітнього процесу;

- збирати й опрацьовувати статистичні дані;

- забезпечити фінансовий і бухгалтерський облік;

- здійснити моніторинг навчальної діяльності закладів освіти;

- створити електронні бази даних працівників УО й кадрів підпорядкованих освітніх закладів;

- забезпечити роботу сайту, вебсторінки навчальних проєктів;

- розширити інформаційну взаємодію та комунікаційні контакти соціального партнерства з УО інших міст, країн;

- забезпечити ефективними електронними навчально-методичними матеріалами.

Сдине інформаційне освітнє середовище поєднує широкий вибір навчального програмного забезпечення та мережних технологій, включаючи електронну пошту, форуми, програмне забезпечення колективного використання, чати, відеоконференції, записи аудіо й відео й широке коло навчальних інструментів, що базуються на використанні вебтехнологій. Така можливість, що створена завдяки різноманітним діалоговим системам, дозволяє здійснювати спілкування в реальному часі.

В умовах широкого проникнення ІКТ в усі сфери життєдіяльності людини поступово змінюється і розуміння сутності освіти. Якщо раніше вона ототожнювалася з формальним, тобто структурованим (з боку цілей, часу й ресурсів) навчанням, яке надається за освітніми програмами в ліцензованих закладах освіти й закінчується сертифікацією або видачею диплома організованим і тривалим процесом у рамках спеціальної системи, створеної для реалізації освітніх цілей, [7, с. 99]. то тепер поняття «освіта» є набагато ширшим поняттям, складовою частиною якого є не лише формальне, а й неформальне, інформальне й соціальне навчання. Розширилися і форми здобуття освіти: інституційна (очна (денна, вечірня), заочна, дистанційна, мережева); індивідуальна (екстернатна, сімейна (домашня), педагогічний патронаж, на робочому місці (на виробництві); дуальна [6].

Розбудова повнофункціональної сучасної освіти протягом життя на основі інформаційних технологій привела до появи відкритої системи освіти - освіти без бар'єрів, доступної для всіх охочих навчатися.

Відкриту освіту слід розуміти як систему, в якій реалізується процес отримання знань на основі принципів інформатизації, демократизації та інтеграції за допомогою новітніх інформаційно-комунікаційних технологій. До ii арсеналу технологій та інструментів належать засоби забезпечення доступу до навчальних матеріалів 
(передусім, електронні бібліотечні системи), засоби візуалізації, інструменти колективної роботи з різноплановим освітнім контентом (як у рамках самого навчального процесу, так і для підготовки до занять педагогів), а також широкий спектр засобів забезпечення сучасної дистанційної освіти - насамперед засоби аудіо- й відеозв'язку. Як правило, засоби відкритої освіти представлено підручниками, онлайн-курсами, тестами, мультимедіями, програмним забезпеченням та інгим.

3 розвитком сучасних інформаційно-комунікаційних технологій та їхнім застосуванням в усіх сферах життя, а також зі збільшенням кількості та якості інформації, обробка засвоєння якої неможлива без відповідного впровадження інформаційних технологій, постає питання формування державної політики розвитку інформаційного суспільства.

Нині існує безліч думок щодо визначення поняття «інформаційне суспільство». Дослідник В.О. Ільганаєва визначає інформаційне суспільство як «нову історичну фазу розвитку цивілізації, життя та діяльність котрої насамперед пов'язані зі створенням, переробленням і використанням інформації» [8, с. 154], а В.О. Данильян розглядає таке суспільство як «якісно новий етап соціотехнологічної еволюції суспільства, що формується в результаті довгострокового соціально-економічного розвитку, що передбачає збільшення ролі інформації та знань, а також формування та споживання інформаційних ресурсів у всіх сферах життєдіяльності суспільства за допомогою розвитку інформаційно-комунікаційних технологій, що існують у глобальних масштабах» [9, с. 23].

В інформаційному суспільстві змінюється роль держави, форми й методи, механізми державного управління, управлінських комунікацій. Сам процес становлення в Україні інформаційного суспільства безпосередньо залежить від рівня інтегрованості новітніх ІКТ до освітнього середовища. Активний інформаційний обмін, що здійснюється у всіх сферах, стає основою життєдіяльності людини інформаційного суспільства, а освіта - тією сферою суспільних відносин, що сприяє адаптації людини до динамічних змін в умовах поширення інтенсивних інформаційних потоків.

Висновки з дослідження і перспективи подальших розвідок у цьому напрямі. Наскрізне застосування інформаційно-комунікаційних технологій в освітньому процесі й управлінні закладами освіти й системою освіти має стати інструментом забезпечення успіху Нової української школи. ІКТ суттєво розширять можливості педагога й оптимізують управлінські процеси. Інформаційно-комунікаційні технології стали невіддільною складовою частиною сучасного суспільства. Впровадження в освіту ІКТ сприяє підвищенню якості освіти, удосконаленню організації закладів загальної середньої освіти й управління ними. Впровадження новітніх інформаційних систем в освіті дозволяє оптимізувати організаційний та управлінський процес. Освіта як соціальний інструмент натепер потребує трансформаційних змін: IКТ виступають у ролі як каталізатору цих змін, так і інструменту для їх реалізації. Перехід України до демократичного суспільства, правової держави й ринкової економіки зумовлює необхідність запровадження державної освітньої політики, яка відповідала б потребам сьогодення. Адже саме освіта становить стратегічний ресурс соціально-економічного й науково-технічного розвитку суспільства, поліпшення добробуту людей, забезпечення національних інтересів, зміцнення авторитету й конкурентоспроможності держави на міжнародній арені.

Подальші наші дослідження будуть спрямовані на визначення реалізації прав на вільний пошук, одержання, передачу, виробництво й поширення інформації; здійснення підготовки необхідних спеціалістів і кваліфікованих користувачів; вивчення умов щодо подолання цифрової нерівністі в доступі громадян України до електронних комунікацій та інформаційних ресурсів.

\section{Список використаних джерел:}

1. Про схвалення Стратегії розвитку інформаційного суспільства в Україні : Розпорядження Кабінету Міністрів України від 15 травня 2013 р. № 386-р. Урядовий портал : Єдиний вебпортал органів виконавчої влади України. URL: https://zakon.rada.gov.ua/laws/show/386-2013-\%D1\%80\#Техt (дата звернення: 01.09.2020).

2. Про Рекомендації парламентських слухань на тему: «Реформи галузі інформаційно-комунікаційних технологій та розвиток інформаційного простору України» : Постанова Верховної Ради України від 31 березня 2016 р. № 1073-VIII / Верховна Рада України. URL: https://zakon.rada.gov.ua/laws/show/1073-19\#Техt (дата звернення: 01.09.2020).

3. Про освіту : Закон України від 05 вересня 2017 р. №2145-VIII / Верховна Рада України. URL: http://zakon3.rada.gov.ua/laws/show/2145-19/ (дата звернення 01.09.2020).

4. Концепція Нової української школи / Міністерство освіти і науки України. URL: https://mon.gov.ua/ua/tag/ nova-ukrainska-shkola (дата звернення 02.09.2020).

5. Інформаційно-комунікаційні технології. Вікіпедія: вільна енциклопедія. URL: uk.wikipedia.org/wiki/Iнформаційно-комунікаційні_технології (дата звернення: 02.09.2020).

6. Биков В.Ю. Моделі організаційних систем відкритої освіти : монографія. Київ : Атіка, 2008. 684 с.

7. Tissot Ph. Terminology of European education and training policy : a selection of 130 key terms. Second edition. Luxembourg : Publications office of the european union, 2014. 338 p. 
8. Социальные коммуникации (теория, методология, деятельность) : словарь-справочник / сост. В.А. Ильганаева. Харьков : КП «Городская типография», 2009. 392 с.

9. Данильян В.О. Інформаційне суспільство та перспективи його розвитку в Україні (соціально- філософський аналіз) : монографія. Харків : Право, 2008. 184 с.

\section{References:}

1. Rozporyadzhennya Kabinetu Ministriv Ukrayiny «Pro skhvalennya Stratehiyi rozvytku informatsiynoho suspilstva v Ukrayini» vid 15.05.2013 № 386-r. // Ofitsiynyy visnyk Ukrayiny vid 21.06.2013. - 2013 r., № 44, stor. 79 , stattya 1581, kod akta 67438/2013

2. Postanova Verkhovnoyi Rady Ukrayiny «Pro Rekomendatsiyi parlamentskykh slukhan na temu: «Reformy haluzi informatsiyno-komunikatsiynykh tekhnolohiy ta rozvytok informatsiynoho prostoru Ukrayiny» vid 31 bereznya 2016 roku № 1073- VIII. // Vidomosti Verkhovnoyi Rady Ukrayiny vid 22.04.2016. - 2016 r., № 17, stor. 9, stattya 191.

3. Zakon Ukrayiny «Pro osvitu» vid 05.09.2017 №2145 - VIII Ofitsiynyy visnyk Ukrayiny vid 06.10.2017. - 2017 r., № 78, stor. 7, stattya 2392, kod akta 87438/2017

4. Kontseptsiya Novoyi ukrayinskoyi shkoly. URL: https://mon.gov.ua/ua/tag/nova-ukrainska-shkola (data zvernennya 02.09.2020 r.)

5. Informatsiyno-komunikatsiyni tekhnolohiyi. URL: uk.wikipedia.org/wiki/Informatsiyno-komunikatsiyni_ tekhnolohiyi (data zvernennya 02.09.2020)

6. Bykov V.YU. Modeli orhanizatsiynykh system vidkrytoyi osvity : monohrafiya / V.YU. Bykov. - K. : Atika, 2008. $-684 \mathrm{~s}$.

7. Tissot Ph. Terminology of European education and training policy : a selection of 130 key terms / Ph. Tissot. [second edition]. - Luxembourg : Publications office of the european union, 2014. - $338 \mathrm{p}$.

8. Sotsialnyye kommunikatsii (teoriya, metodologiya, deyatelnost) [Tekst]: slovar-spravochnik / sost. V. A. Ilganayeva. - KH. KP «Gorodskaya tipografiya», 2009. - 392 s.

9. Danylyan V. O. Informatsiyne suspilstvo ta perspektyvy yoho rozvytku v Ukrayini (sotsialno-filosofskyy analiz) [Tekst] : monohrafiya / V. O. Danylyan. - KH. : Pravo, 2008. - 184 s. 